\title{
Experimental Research \\ Brain oxygen monitoring: in-vitro accuracy, long-term drift and response-time of Licox- and Neurotrend sensors
}

\author{
B. M. Hoelper ${ }^{1}$, B. Alessandri ${ }^{2}$, A. Heimann ${ }^{2}$, R. Behr ${ }^{1}$, and O. Kempski ${ }^{2}$ \\ ${ }^{1}$ Department of Neurosurgery, Klinikum Fulda, Academic Hospital of the Philips University Marburg, Fulda, Germany \\ ${ }^{2}$ Institute of Neurosurgical Pathophysiology, Johannes Gutenberg-University of Mainz, Mainz, Germany
}

Received August 2, 2004; accepted February 4, 2005; published online May 13, 2005

(C) Springer-Verlag 2005

\section{Summary}

Background. Oxygen tension sensors have been used to monitor tissue oxygenation in human brain for several years. The working principals of the most frequently used sensors, the Licox (LX) and Neurotrend (NT), are different, and they have never been validated independently for correct measurement in vitro. Therefore, we tried to clarify if the two currently available sensors provide sufficient accuracy and stability.

Method. 12 LX oxygen tension sensors and NT sensors were placed into a liquid-filled tonometer chamber. The solution was kept at $37 \pm 0.2^{\circ} \mathrm{C}$ and equilibrated with five calibration gases containing different $\mathrm{O}_{2}$ - and $\mathrm{CO}_{2}$-concentrations. After equilibration, readings were taken for each gas concentration (accuracy test). Afterwards, the sensors were left in $3 \% \mathrm{O}_{2}$ and $9 \% \mathrm{CO}_{2}$ and readings were taken after 24, 48, 72, 96 and 120 hours (drift test). Thereafter, a $90 \%$ response time test was performed transferring sensors from $1 \%$ to $5 \%$ oxygen concentration and back, using pre-equilibrated tonometers.

Findings. All Licox oxygen probes [12] were used for this study. Two of 14 Neurotrend sensors did not calibrate, revealing a failure rate of $14 \%$ for NT. Oxygen tension during the accuracy test was measured as follows: $1 \% \quad \mathrm{O}_{2}(7.1 \mathrm{mmHg}): \mathrm{LX} \quad 6.5 \pm 0.4$, NT $5.3 \pm 2.3 \mathrm{mmHg}$, $2 \% \mathrm{O}_{2}(14.2 \mathrm{mmHg}): \mathrm{LX} 12.9 \pm 0.6$, NT $12.1 \pm 2.2 \mathrm{mmHg}, 3 \% \mathrm{O}_{2}$ (21.4 mmHg): LX $19.8 \pm 0.7, \quad \mathrm{NT} \quad 19.4 \pm 2.4 \mathrm{mmHg}, \quad 5 \% \quad \mathrm{O}_{2}$ $(35.8 \mathrm{mmHg}): \quad \mathrm{LX} \quad 33.4 \pm 1.0 \mathrm{mmHg}, \quad \mathrm{NT} \quad 33.5 \pm 2.9 \mathrm{mmHg}$, $8 \% \mathrm{O}_{2}(57.0 \mathrm{mmHg}): 53.8 \pm 1.5$, NT $53.6 \pm 3.3 \mathrm{mmHg}$. After 120 hours in $3 \% \mathrm{O}_{2}(21 \mathrm{mmHg})$, LX measured $19.8 \pm 1.9 \mathrm{mmHg}$, NT $17.9 \pm 4.7 \mathrm{mmHg}$. $90 \%$ response time from $1 \%$ to $5 \% / 5 \%$ to $1 \%$ oxygen concentration was $129 \pm 27 / 174 \pm 26 \mathrm{sec}$ for LX, $55 \pm 19 / 98 \pm 39 \mathrm{sec}$ for NT.

Conclusions. Both systems are measuring oxygen tension sufficiently, but more accurately with LX probes. NT sensors read significantly lower $\mathrm{pO}_{2}$ in $1 \% \mathrm{O}_{2}$ and show an increasing deviation with higher oxygen concentrations which was due to two of twelve probes. A slight drift towards lower oxygen tension readings for both sensors but more pronounced for the NT does not impair long-term use. NT measures $\mathrm{pCO}_{2}$ and $\mathrm{pH}$ very accurately.

Keywords: Licox; Neurotrend; $\mathrm{pO}_{2}$; drift; accuracy; response time; in vitro.

\section{Introduction}

Catheter probes designed to measure partial pressure of oxygen $\left(\mathrm{pO}_{2}\right)$ in human brain tissue have been in use for the last several years. They might support clinicians to receive an extended overview about pathophysiological conditions during critical episodes in neurological and neurosurgical diseases additionally to routine monitoring of ICP. Following head injury, $\mathrm{pO}_{2}$ measurement in injured brain tissue has been evolved to a reliable method to monitor cerebral oxygenation, which can be substantially compromised due to reduced cerebral blood flow, brain swelling or increased brain metabolism [4, 22, 23, 26]. Furthermore, it is described to survey cerebral oxygenation for treating increased intracranial pressure [11, $18,21,24,26,27]$. The risk for cerebral ischemia due to reduced cerebral blood flow can also be monitored by this method following subarachnoid haemorrhage $[2,5,7,9$, $10,17]$ and stroke [6, 19]. Two currently available systems are based on different technologies: an electrochemical $\mathrm{pO}_{2}$-sensor (Licox, LX) and a fluorescent $\mathrm{pO}_{2}$ sensor (Neurotrend, NT). However, until now no study clarified the in vitro performance of these clinically applied sensors. But before these catheters are used to measure physiological and pathophysiological conditions in brain tissue, data from in vitro studies should be generated testing three important sensor requirements: reading of accurate absolute values, low drift over time and quick response to changes. Since this has not be done before, this study describes the in vitro characteristics 
of both analysed catheter probes investigating the accuracy, drift and response-time test.

\section{Materials and methods}

For each of six experimental setups, 2 new electrochemical oxygen tension sensors (Licox, CC1.SB Catheter $\mathrm{pO}_{2}$ microprobe, Integra NeuroSciences Ltd., Hamphsire, UK), 2 new "Licox" temperature sensors (LT, Integra Neuroscience Ltd., UK) and 2 new fluorescent sensors which passed the calibration process (NT, Codman Neurotrend Multiparameter sensor, Codman\&Shurtleff, Raynham, USA) were used. The Clark-type LX-sensors used in this study have a diameter of $0.45 \mathrm{~mm}$, a $\mathrm{pO}_{2}$ - sensitive sensor length of $5 \mathrm{~mm}$ and a surface area for measuring $\mathrm{pO}_{2}$ mentioned in the literature between 7.1 and $15 \mathrm{~mm}^{2}[4,13]$. The NT sensor used in this report integrates three optical sensors $(\mathrm{pH}$ sensor is anchored to the tip of the sensor, followed by $\mathrm{pCO}_{2}$ - and $\mathrm{pO}_{2}$-sensor) and a thermocouple in one catheter probe. The complete NT catheter probe is $17.5 \mathrm{~mm}$ in length, $0.5 \mathrm{~mm}$ in diameter, and individual optical fibres are $0.175 \mathrm{~mm}$ in diameter (data provided by manufacturer).

The catheter probes were placed into a closed container filled with a tonometer solution $\left(1000 \mathrm{~g}\right.$ distilled water, added $1.91 \mathrm{~g} \mathrm{NaHCO}_{3}$ and $14.01 \mathrm{~g} \mathrm{Na}_{2} \mathrm{SO}_{4}$ ). The solution was kept at $37 \pm 0.2^{\circ} \mathrm{C}$ in a waterbath throughout the complete monitoring time and equilibrated with five highly precise calibration gases (certified after DIN 51895, ISO 9001, Linde Gas AG, Bottrop, Germany), containing different $\mathrm{O}_{2^{-}}$and $\mathrm{CO}_{2^{-}}$ concentrations (Table 1). For the accuracy test, the tonometer solution was equilibrated with each gas concentration for 30 minutes. After each equilibration period, sensor readings were taken for 20 minutes. After measurements for each gas concentration were finished, all sensors were left in one gas concentration (calibration gas \#3 with $3 \% \mathrm{O}_{2}$ and $9 \%$ $\mathrm{CO}_{2}$ ) and readings were taken after 24, 48, 72, 96 and 120 hours (drift test). For determination of $90 \%$ response time, the sensors were placed into a tonometer which was pre- equilibrated with calibration gas \#1 (1\% $\mathrm{O}_{2}, 5 \% \mathrm{CO}_{2}$ ). After an equilibration period of 15 minutes, sensors were transferred to a second tonometer pre-equilibrated with calibration gas \#5 $\left(8 \% \mathrm{O}_{2}, 16 \% \mathrm{CO}_{2}\right)$. After additional 15 minutes of equilibration period, sensors were placed back to calibration gas \#1. Sensor readings were taken every 10 seconds over the complete response time test. The
Table $1 . \mathrm{O}_{2}$ and $\mathrm{CO}_{2}$ concentrations (\%) in the calibration gases (gas \#1-\#5). Relative measurement deviation $( \pm \%)$ are related to the concentration of each gas. $\mathrm{O}_{2}, \mathrm{pCO}_{2}$ are calculated assuming 1013 mbar barometric pressure, $\mathrm{pH}$ calculation please see method section

\begin{tabular}{llrrrr}
\hline $\begin{array}{l}\text { Calibration } \\
\text { gas \# }\end{array}$ & $\% \mathrm{O}_{2}$ conc. & $\mathrm{mmHg}$ & $\% \mathrm{CO}_{2}$ conc. & $\mathrm{mmHg}$ & $\mathrm{pH}$ \\
\hline 1 & $1.01( \pm 2 \%)$ & 7.13 & $5.02( \pm 1 \%)$ & 35.78 & 7.347 \\
2 & $1.99( \pm 2 \%)$ & 14.18 & $6.97( \pm 1 \%)$ & 49.68 & 7.205 \\
3 & $3.00( \pm 2 \%)$ & 21.38 & $9.04( \pm 1 \%)$ & 64.44 & 7.092 \\
4 & $5.02( \pm 1 \%)$ & 35.78 & $11.94( \pm 1 \%)$ & 85.11 & 6.971 \\
5 & $8.00( \pm 1 \%)$ & 57.03 & $16.00( \pm 1 \%)$ & 114.05 & 6.844 \\
\hline
\end{tabular}

time taken to reach $90 \%$ of the signal change of the sensor measured after 15 minutes equilibration time was calculated (90\% response time).

Bath temperature at the time of sensor readings was measured by a precision measuring instrument (P555, temperature probe PT100, Dostmann electronics GmbH, Wertheim, Germany). NT measures temperature within the same catheter and automatically corrected $\mathrm{pO}_{2}$ for temperature, while $\mathrm{LX}$ requires an additional temperature probe.

Barometric pressure $[\mathrm{hPa}]$ recorded every minute (Institute of physics of atmosphere, Johannes Gutenberg-University Mainz, Germany) was converted to $[\mathrm{mmHg}]$ by the following constant: $760 \mathrm{mmHg} *$ $1.333224=1013.25 \mathrm{hPa}$. After subtracting the partial pressure due to water vapour $(47.6 \mathrm{mmHg})$, the partial pressure was calculated depending on oxygen concentration in each gas by the following equation:

$$
\begin{aligned}
\text { Partial pressure }[\mathrm{mmHg}]= & ((\text { Barometric pressure }[\mathrm{mmHg}] \\
& \left.- \text { water vapour }\left[47.6 \mathrm{mmHg} \text { for } 37^{\circ} \mathrm{C}\right]\right) \\
& * \text { oxygen concentration }[\mathrm{mmHg}]) / 100
\end{aligned}
$$

The $\mathrm{pH}$ of the buffer solution was calculated as follows:

$$
\mathrm{pH}=7.203-\log \left(\% \mathrm{CO}_{2} / 7\right)-0.007146
$$

Data of all monitors connected to the sensors were transferred via RS-232 ports to a RS-232/USB Hub (Edgeport, InsideOut Networks, Austin, Texas, USA) and collected in a time-locked PC using a data collecting software (ICU-Pilot, CMA Microdialysis, Solna, Sweden) as

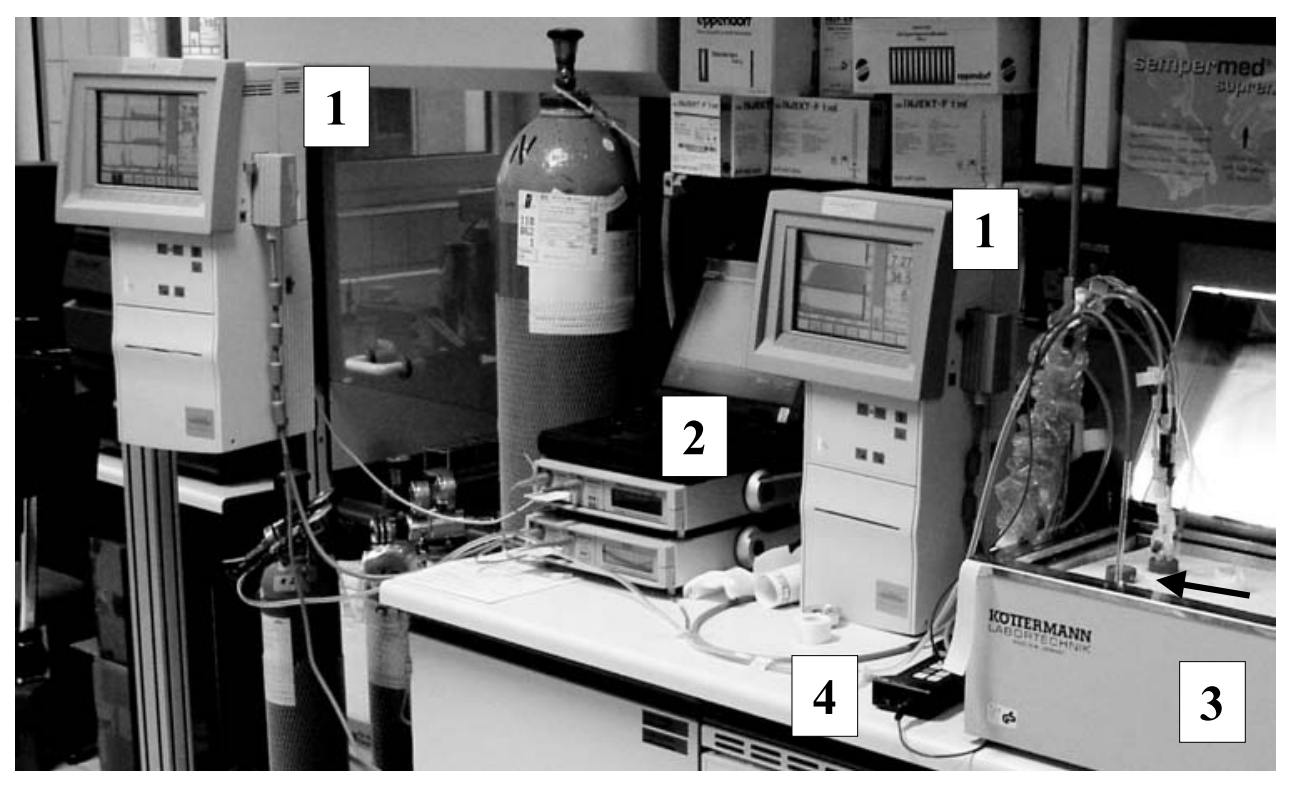

Fig. 1. Setup of the in-vitro experiment shows the waterbath (right, 3) and two PC collecting data from the Neurotrend (1) and Licox monitors (2) via ICU-Pilot ${ }^{\circledR}$. A PT100 temperature probe was used as reference to monitor the waterbath temperature (4). Note that the sensors are mounted in two tonometers (arrow) which are bubbled continuously with predefined gas mixtures 
shown in Fig. 1. Data are presented as means \pm standard deviation. Statistical analysis (Mann-Whitney-U-Test) was performed by SPSS Software (Release 11.0.1, SPSS Inc., Illinois, USA). A p-value of $<0.05$ was considered to be statistically significant. All authors confirm that both experimental setup and data analysis was not influenced by any company, even if this study was financially supported by Codman\& Shurtless, Raynham, USA, distributor of the Neurotrend sensor.

\section{Results}

\section{Accuracy of $\mathrm{pO}_{2}$ readings}

Two of 14 NT probes were rejected due to a failed calibration procedure. 12 NT probes with a successful calibration were further analyzed. No technical failure was found in all 12 Licox sensors calibrated during the manufacture process. For each LX probe a chip card containing the calibration data was inserted into the Licox monitor. Figure 2 shows the $\mathrm{pO}_{2}$ readings for both the LX and NT sensor probe in the tonometer solution bubbled with the five different calibration gases. In calibration gas \#1 and \#2 (low oxygen concentrations), measurements of NT and LX were $1.8-1.9 \mathrm{mmHg}$ and $0.6-1.1 \mathrm{mmHg}$, respectively, lower than the $\mathrm{pO}_{2}$ calculated by $\mathrm{O}_{2^{-}}$ concentration of calibration gases. For higher oxygen concentrations (gas \#3-\#5), deviations further increased slightly for both NT and LX (Table 2). $\mathrm{pO}_{2}$ measured in calibration gas \#1 (1\%/7 mmHg $\left.\mathrm{pO}_{2}\right)$ was significantly different between NT and LX $(\mathrm{p}<0.01$; Table 2). In calibration gases \#2-\#5 no statistically significant difference

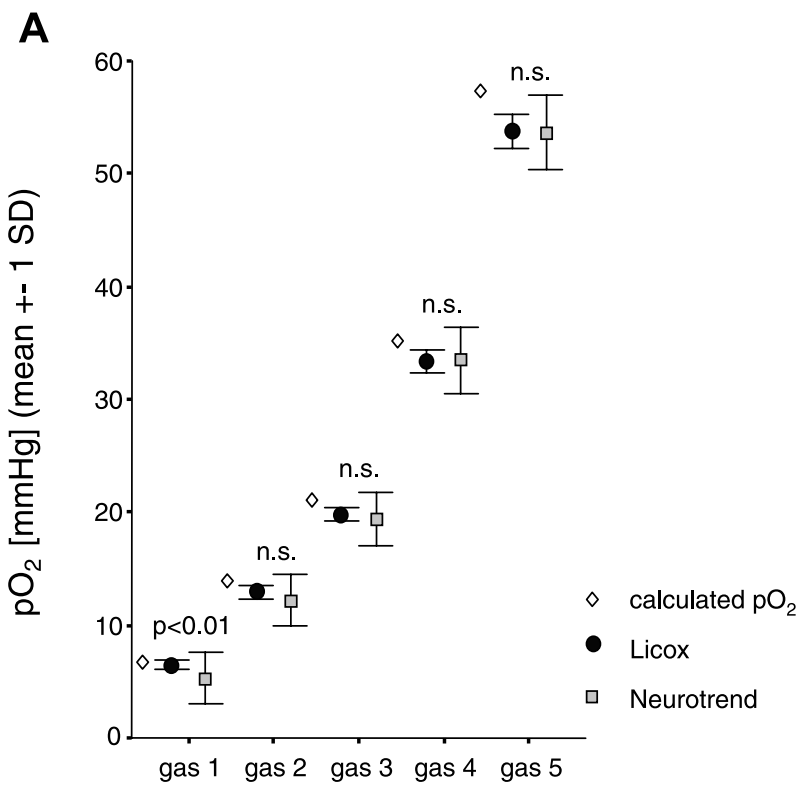

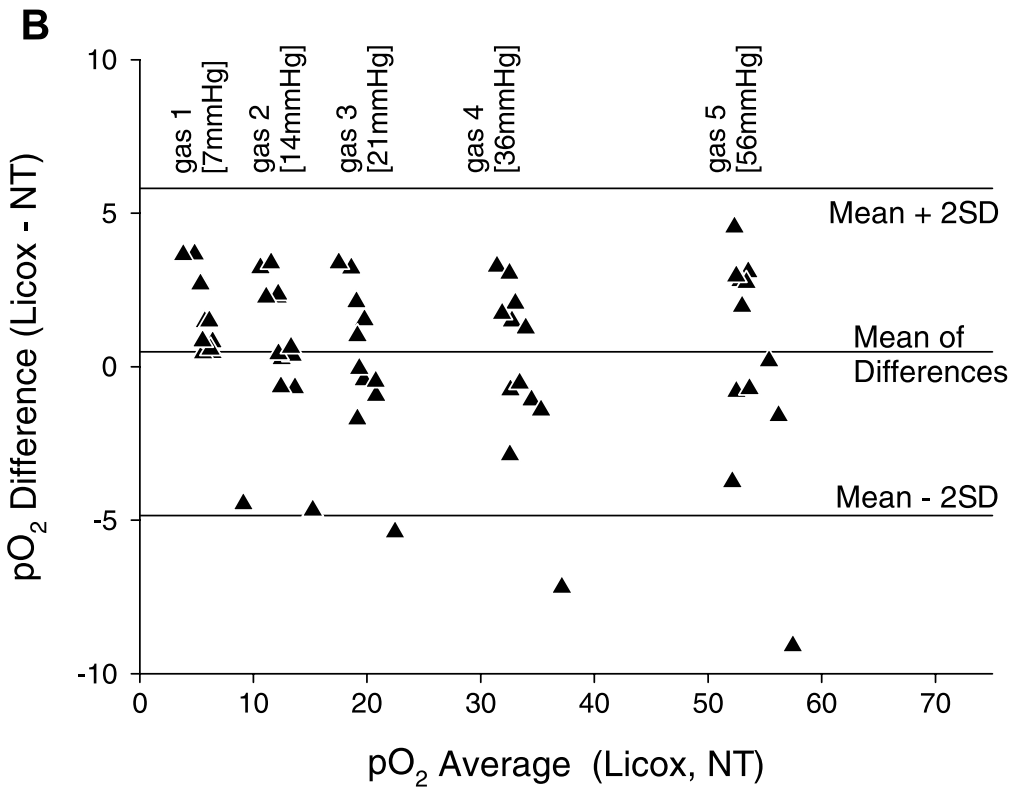

Fig. 2. Distribution of measured $\mathrm{pO}_{2}$ concentrations $[\mathrm{mmHg}]$ in comparison with the expected/calculated oxygen values (A) and comparison of the two oxygen measurement methods by a Bland-Altman plot (B) using different test gases (gas 1-5). In the upper graph (A), an accuracy test of Licox $(L X)$ and Neurotrend (NT) $\mathrm{pO}_{2}$ probes (correctly calculated $\mathrm{pO}_{2}$ is represented by $\diamond$, see Table 1) was performed in five different high precision calibration gases. Data of LX and NT are shown in mean \pm standard deviation. In the lower graph (B) the differences of LX and NT oxygen readings are plotted against the mean of LX and NT values (12 pairs/gas concentration). This plot indicates that at each calibration gas the NT measuring method is comparable to the 'gold standard' of LX, although NT sensors read lower values at low oxygen concentrations and show a high variability between probes at high oxygen concentrations 
Table 2. Results of accuracy test with absolute values of $\mathrm{PO}_{2}$ in all five calibration gases measured by $L X$ and $N T$ sensor probes ( $p \mathrm{O}_{2}$ meas) compared to the calculated partial pressure $\left(\mathrm{pO}_{2}\right.$ calc) corrected by local barometric pressure. $\mathrm{pO}_{2}$ diff represents the difference between the calculated and measured $\mathrm{pO}_{2}$ corrected to the time dependent local barometric pressure

\begin{tabular}{|c|c|c|c|c|c|}
\hline \multirow[t]{2}{*}{ Gas } & \multirow[t]{2}{*}{$\mathrm{pO}_{2 \text { calc }}$} & \multicolumn{2}{|l|}{$\mathrm{pO}_{2}$ meas } & \multicolumn{2}{|l|}{$\mathrm{pO}_{2}$ diff } \\
\hline & & $L X$ & $N T$ & $L X$ & $N T$ \\
\hline 1 & $7.11 \pm 0.24$ & $6.47 \pm 0.43$ & $5.27 \pm 2.30$ & $0.64 \pm 0.45$ & $1.84 \pm 2.30$ \\
\hline 2 & $14.02 \pm 0.49$ & $12.90 \pm 0.56$ & $12.15 \pm 2.28$ & $1.11 \pm 0.55$ & $1.87 \pm 2.29$ \\
\hline 3 & $21.13 \pm 0.75$ & $19.79 \pm 0.66$ & $19.43 \pm 2.39$ & $1.34 \pm 68$ & $1.71 \pm 2.41$ \\
\hline 4 & $35.37 \pm 0.12$ & $33.38 \pm 1.00$ & $33.46 \pm 2.89$ & $1.99 \pm 0.97$ & $1.91 \pm 2.92$ \\
\hline 5 & $56.37 \pm 0.19$ & $53.82 \pm 1.52$ & $53.63 \pm 3.27$ & $2.55 \pm 1.51$ & $2.73 \pm 3.32$ \\
\hline
\end{tabular}

$\mathrm{pO}_{2}$ calc, $\mathrm{pO}_{2}$ meas in $[\mathrm{mmHg}]$.

was found. The difference between the partial pressure in the tonometric solution corrected for the local barometric pressure and the measured partial pressure by LX and NT are shown in Table 2.

After equilibration in constant gas concentrations, partial pressure measurement of oxygen was more heterogeneous in NT compared with LX, leading to higher standard deviations (Fig. 2, Table 2). This was not due to the reduced numerical data delivered by the NT monitor (integer numbers) compared with LX (rational numbers). The higher heterogeneity of the NT persists also after rounding the rational numbers of LX. Mainly two NT sensors $(16.7 \%)$ added to the higher standard deviation of NT probes. The Bland-Altman plot indicates that both methods are comparable in low oxygen concentrations, but with a tendency of lower readings by NT. At high oxygen concentrations NT measurements deviate more from the ones recorded by Licox (Fig. 2B).

\section{Drift of $\mathrm{pO}_{2}$}

Measurements for both sensors left in calibration gas \#3 $\left(3 \% \mathrm{O}_{2}\right)$ were taken after 24, 48, 72, 96 and 120 hours (Fig. 3). The differences between the real $\mathrm{pO}_{2}$ corrected for local barometric pressure and the measured $\mathrm{pO}_{2}$ is summarised in Table 3. Absolute $\mathrm{pO}_{2}$

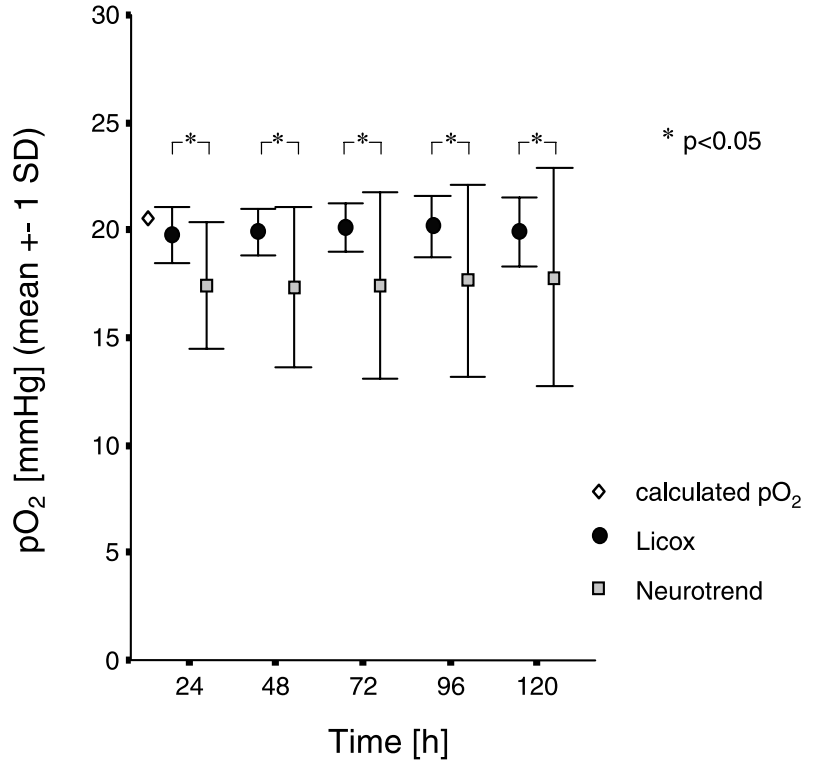

Fig. 3. Stability test over 5 consecutive days for Licox and Neurotrend sensors. Drift of $\mathrm{pO}_{2}[\mathrm{mmHg}]$ was measured over time in probes equilibrated in tonometric solution with calibration gas \#3 (calculated: $21.13 \pm 0.75 \mathrm{mmHg} \mathrm{pO}_{2}$, depending on atmospheric pressure)

measured by NT is $3.2-4.1 \mathrm{mmHg}$ lower than $\mathrm{pO}_{2}$ calculated by $\mathrm{O}_{2}$-concentrations depending on atmospheric pressure in the tonometer $\left(\mathrm{pO}_{2}\right.$ of $\left.21.13 \pm 0.75 \mathrm{mmHg}\right)$. LX sensors measured 1.0-1.4 mmHg lower $\mathrm{pO}_{2}$ (Table 3)

Table 3. Results of drift test with measurement of $\mathrm{pO}_{2}$ every 24 hours for five days (time) by LX and NT sensor probes ( $\mathrm{pO} \mathrm{O}_{2}$ meas) compared to the calculated partial pressure $\left(\mathrm{pO}_{2}\right.$ calc) corrected by local barometric pressure. $\mathrm{pO}_{2}$ diff represents the difference between the calculated and measured $\mathrm{pO}_{2}$ corrected to the time dependent local barometric pressure

\begin{tabular}{|c|c|c|c|c|c|}
\hline \multirow[t]{2}{*}{ Time } & \multirow[t]{2}{*}{$\mathrm{pO}_{2 \text { calc }}$} & \multicolumn{2}{|l|}{$\mathrm{pO}_{2}$ meas } & \multicolumn{2}{|l|}{$\mathrm{pO}_{2 \text { diff }}$} \\
\hline & & $L X$ & $N T$ & $L X$ & $N T$ \\
\hline $24 \mathrm{~h}$ & $21.1 \pm 0.06$ & $19.7 \pm 1.3$ & $17.6 \pm 3.0$ & $1.4 \pm 1.3$ & $3.7 \pm 2.9$ \\
\hline $48 \mathrm{~h}$ & $21.2 \pm 0.08$ & $19.9 \pm 1.0$ & $17.1 \pm 3.2$ & $1.3 \pm 1.0$ & $3.8 \pm 3.7$ \\
\hline $72 \mathrm{~h}$ & $21.2 \pm 0.09$ & $20.2 \pm 1.0$ & $17.3 \pm 3.9$ & $1.1 \pm 1.0$ & $3.7 \pm 4.3$ \\
\hline $96 \mathrm{~h}$ & $21.2 \pm 0.1$ & $20.1 \pm 1.3$ & $18.0 \pm 4.3$ & $1.0 \pm 1.3$ & $3.5 \pm 4.5$ \\
\hline $120 \mathrm{~h}$ & $21.2 \pm 0.1$ & $19.8 \pm 1.9$ & $17.9 \pm 4.7$ & $1.3 \pm 1.6$ & $3.4 \pm 5.1$ \\
\hline
\end{tabular}

$\mathrm{pO}_{2}$ calc, $\mathrm{pO}_{2}$ meas in $[\mathrm{mmHg}]$. 
Table 4. Results of accuracy test with absolute values of $\mathrm{pCO}_{2}$ and $\mathrm{pH}$ in all five calibration gases measured by $\mathrm{NT}_{\text {sensor probes }}\left(\mathrm{pCO} \mathrm{C}_{2}\right.$ meas, $\mathrm{pH}_{\text {meas }}$ ) compared to the calculated partial pressure $\left(\mathrm{pCO}_{2}\right.$ calc, $\left.\mathrm{pH}_{\text {calc }}\right)$ corrected by local barometric pressure

\begin{tabular}{lrrll}
\hline Gas $\left(\% \mathrm{pCO}_{2}\right)$ & \multicolumn{1}{c}{$\mathrm{pCO}_{2 \text { calc }}$} & \multicolumn{1}{c}{$\mathrm{pCO}_{2 \text { meas }}$} & $\mathrm{pH}$ calc & $\mathrm{pH}$ meas \\
\hline 5.02 & $35.36 \pm 0.14$ & $35.38 \pm 1.78$ & $7.347 \pm 0.021$ & $7.36 \pm 0.06$ \\
6.97 & $49.15 \pm 0.20$ & $49.48 \pm 2.11$ & $7.205 \pm 0.018$ & $7.23 \pm 0.07$ \\
9.04 & $63.77 \pm 0.27$ & $63.69 \pm 2.25$ & $7.092 \pm 0.012$ & $7.11 \pm 0.06$ \\
11.94 & $84.23 \pm 0.33$ & $84.88 \pm 3.30$ & $6.971 \pm 0.008$ & $7.00 \pm 0.07$ \\
16.00 & $112.80 \pm 0.43$ & $112.98 \pm 3.11$ & $6.844 \pm 0.008$ & $6.86 \pm 0.06$ \\
\hline
\end{tabular}

$\mathrm{pCO}_{2 \text { calc, }} \mathrm{pCO}_{2 \text { meas }}$ in $[\mathrm{mmHg}]$.

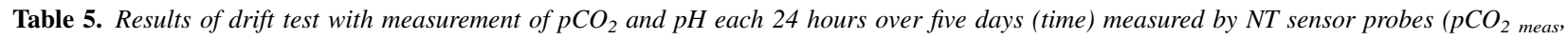
$\left.p \mathrm{H}_{\text {meas }}\right)$. The calculated partial pressure $\left(\mathrm{pCO}_{2}\right.$ calc $)$ is corrected by local barometric pressure, calculation of $\mathrm{pH}_{\text {calc }}$ see text

\begin{tabular}{rllll}
\hline Time & $\mathrm{pCO}_{2 \text { calc }}$ & $\mathrm{pCO}_{2 \text { meas }}$ & $\mathrm{pH}$ calc & $\mathrm{pH}_{\text {meas }}$ \\
\hline $24 \mathrm{~h}$ & $63.70 \pm 0.17$ & $64.03 \pm 2.35$ & $7.094 \pm 0.015$ & $7.13 \pm 0.06$ \\
$48 \mathrm{~h}$ & $63.79 \pm 0.24$ & $63.77 \pm 2.75$ & $7.096 \pm 0.018$ & $7.15 \pm 0.06$ \\
$72 \mathrm{~h}$ & $63.98 \pm 0.26$ & $63.46 \pm 3.10$ & $7.098 \pm 0.020$ & $7.16 \pm 0.07$ \\
$96 \mathrm{~h}$ & $63.89 \pm 0.41$ & $63.19 \pm 3.04$ & $7.100 \pm 0.020$ & $7.19 \pm 0.08$ \\
$120 \mathrm{~h}$ & $63.80 \pm 0.46$ & $63.02 \pm 3.13$ & $7.101 \pm 0.080$ & $7.19 \pm 0.05$ \\
\hline
\end{tabular}

$\mathrm{pCO}_{2 \text { calc }}, \mathrm{pCO}_{2}$ meas in $[\mathrm{mmHg}]$.

and $\mathrm{pO}_{2}$ readings were significantly different between LX and NT after 24 hours and this difference remained over the next 96 hours $(\mathrm{p}<0.05)$. NT sensors showed a more heterogeneous distribution of $\mathrm{pO}_{2}$ and this deteriorated over time. LX sensors showed a very stable measurement of $\mathrm{pO}_{2}$ throughout the drift test and even after $120 \mathrm{~h}$ a low standard deviation was fond (Fig. 3).

\section{$90 \%$ response time to $\mathrm{pO}_{2}$ changes}

$90 \%$ response time after changing sensors from calibration gas \#1 to calibration gas \#5 was $129 \pm 27 \mathrm{sec}$ for LX and $55 \pm 19 \mathrm{sec}$ for NT. After 15 minutes equilibration, $\mathrm{pO}_{2}$ readings of $\mathrm{LX}$ were $1.5 \mathrm{mmHg}$ lower $(54.9 \pm 1.9 \mathrm{mmHg})$ and of NT $5.9 \mathrm{mmHg}$ lower $(50.5 \pm 7.0 \mathrm{mmHg})$ compared with the calculated $\mathrm{pO}_{2}$ in the tonometer solution. After transferring sensors from calibration gas \#5 back to gas \#1, LX needed $174 \pm 26 \mathrm{sec}$ and NT $98 \pm 39 \mathrm{sec}$ to reach $90 \%$ of the total signal change. After equilibration in calibration gas $\# 1$, mean $\mathrm{pO}_{2}$ readings were $7.1 \pm 0.7 \mathrm{mmHg}$ for $\mathrm{LX}$ and $4.4 \pm 4.3 \mathrm{mmHg}$ for NT sensors.

\section{Accuracy and drift of $\mathrm{pCO}_{2}$ and $\mathrm{pH}$}

Since LX does not measure $\mathrm{pCO}_{2}$ and $\mathrm{pH}$, data of both parameters concerning accuracy and drift are shown for NT only. The difference between $\mathrm{pCO}_{2}$ in the tonometer solution (corrected for barometric pressure) and $\mathrm{pCO}_{2}$ measured by NT was less than $1 \mathrm{mmHg}$ for all $\mathrm{CO}_{2}$ concentrations in the calibration gases. Differences of calculated and measured $\mathrm{pH}$ were less than 0.05 units (Table 4). There is no significant drift over 120 hours for both $\mathrm{pCO}_{2}$ and $\mathrm{pH}$ measurement (Table 5).

\section{Discussion}

Clinical studies have shown for LX sensors a low zerodrift of $1.1 \pm 0.9 \mathrm{mmHg}$, a high "good data quality" of $95 \%$ and a low sensitivity-drift of $1.4 \pm 1.3 \mathrm{mmHg}$ [15]. However, until now there exists no in vitro analysis of the NT sensor along with the LX sensor focussing on the technical properties of both sensors. Therefore, we used a standardised setup to evaluate both sensors and to minimise methodical errors: high precision gases were used to minimise deviation in gas concentrations, partial pressure reference values for oxygen and carbon dioxide were corrected to external barometric pressure, darkening of the tonometer excluded external light influences to the fiberoptic probes and buffer temperature in the tonometer was kept constant to $37 \pm 0.2{ }^{\circ} \mathrm{C}$. NT sensors packed in the pouch which is pre-filled with the first calibration gas were taken out immediately before the calibration process because they should not be left outside the pouch for hours before calibrating due to compromised $\mathrm{pO}_{2}$ accuracy. However, both sensors measure $\mathrm{pO}_{2}$ slightly lower compared with the reference value (calculated by oxygen concentration and barometric pressure). Furthermore, $\mathrm{pO}_{2}$ readings between both sensors are significantly different for low 
$\mathrm{pO}_{2}(1 \%$ oxygen), but there is no statistically significant difference for higher $\mathrm{O}_{2}$ concentrations. Therefore, we suggest that differences in $1 \% \mathrm{O}_{2}$ concentrations (barometric pressure corrected $\mathrm{pO}_{2} 7.1 \pm 0.2 \mathrm{mmHg}$ ) with deviation of $\mathrm{pO}_{2}$ readings of both sensors (NT $1.8 \pm$ $2.3 \mathrm{mmHg}$ and $\mathrm{LX} 0.64 \pm 0.45 \mathrm{mmHg}$ than expected $\mathrm{pO}_{2}$ ) are mostly caused by the sensor and calibration technique. In the $\mathrm{LX}$ sensor, the electrochemical $\mathrm{pO}_{2}$ sensor firstly described by Clark (2) consists of a cathode (gold) which is maintained at a negative potential relative to a reference anode (silver) and both electrodes are immersed in a potassium chloride electrolyte solution. Oxygen diffuses into this cell through a membrane selectively permeable for oxygen. A reduction of oxygen $\left(\mathrm{O}_{2}+\mathrm{H}_{2} \mathrm{O}+4 \mathrm{e}^{-} \rightarrow 4 \mathrm{OH}^{-}\right)$at the cathode generates a current which can be calculated to a $\mathrm{pO}_{2}$. The $\mathrm{pO}_{2}$ also depends on the applied potential, the size and physical characteristics of the cell, and on the configuration of the electrodes [14]. In contrast, the fluorescent sensors (NT) work completely differently. For each sensor, light of specific wavelength illuminates a sample chamber containing a dye [for $\mathrm{O}_{2}$-sensor: tris (4,7-diphenyl-1,10phenanthroline) ruthenium II chloride; for $\mathrm{CO}_{2^{-}}$and pH-sensor: phenol red]. This incident light is completely or partially absorbed or remitted with a different wavelength. Since each analyse embedded in the dye absorbs characteristic wavelengths in preference to others, measurement of the intensity of the absorbed radiation intensity can yield a measurement of the analyse of interest. Similarly, the intensity of the remitted radiation can be influenced in a known manner by the analyte of interest $\left(\mathrm{pO}_{2}, \mathrm{pCO}_{2}, \mathrm{pH}\right)$. For $\mathrm{pO}_{2}$ measurement, the intensity of the emitted fluorescent light is decreased (quenched) by oxygen $[8,16]$, and the quantitative relationship between the observed fluorescent intensity (I) and $\mathrm{pO}_{2}$ is described by the Stern-Volmer equation $\left(\mathrm{I}=\mathrm{I}_{0} /(1+\mathrm{k} *\right.$ $\left.\mathrm{pO}_{2}\right)$, where $\mathrm{I}_{0}$ is the unquenched intensity $\left(\mathrm{pO}_{2}=\right.$ $0 \mathrm{mmHg}$ ) and $\mathrm{k}$ is the quenching constant [20]. Based on this relationship, one would expect that fiberoptic probes (NT) are more precise compared with Clarc-type electrode (LX) sensors [14] because they are calibrated immediately before usage and have a higher sensitivity for low $\mathrm{pO}_{2}$. The Stern-Volmer equation implicates that the largest changes in intensity with changes in $\mathrm{pO}_{2}$ occur at low values of $\mathrm{pO}_{2}$, so that the method is most accurate at these low values of $\mathrm{pO}_{2}$ [14]). However deviation of $\mathrm{pO}_{2}$ measurements seen with the NT sensor are still within the claimed performance criteria specified by the manufacturer (NT measures $\mathrm{pO}_{2}$ in a range from 10 to $160 \mathrm{mmHg}$, in vitro accuracy of $\pm 3.5 \mathrm{mmHg}$ between 10 to $60 \mathrm{mmHg}$ and $\pm 10 \%$ between 60 to $110 \mathrm{mmHg}, \mathrm{pO}_{2}$ drift $<0.5 \% / \mathrm{h}$ ). It remains unclear why these differences are not seen in the $\mathrm{pCO}_{2}$ probe which also runs fiberoptically but measures much more precisely. However, in this study NT seems to be sensitive to much more technical influences such as calibration procedure, sensor size, diffusion of oxygen into the dye as well as optical accuracy of emitted and detected re-emitted light leading to higher inaccuracy at low oxygen concentrations and standard deviation compared with the LX sensor. The difficult calibration process of NT sensors in combination with the need of very accurate miniaturised catheter production might lead to a higher failure rate of NT catheters, which was $14 \%$ (2 of 14 NT sensors) in this study. The high accuracy of the LX sensor as found in this report is also described by Dings et al. [4] who found a mean of sensitivity error less than $1.1 \%$ with a maximal sensitivity error of -3.87 between $22-37^{\circ} \mathrm{C}$ and $\mathrm{a} \mathrm{O}_{2}$ range of $0-150 \mathrm{mmHg} \%$. For low oxygen concentrations, we suggest a slightly higher sensitivity error: assuming that there is no zero display error, sensitivity error for LX is between $-4.5 \%$ and $9.0 \%$, and for NT between $4.8 \%$ and $25.87 \%$. One reason for this difference might be that Dings et al. evaluated the LX sensors in $6 \%(42.7 \mathrm{mmHg}$ at $760 \mathrm{mmHg}$ atmospheric pressure and $47.6 \mathrm{mmHg}$ water vapour) and $0 \%$ oxygen concentrations only without using a buffer solution and not correcting $\mathrm{pO}_{2}$ for local barometric pressure.

In clinical practice, the sensitivity error of both sensors presumably is of minor importance, since accuracy and drift of both catheters sufficiently allow for differences between a critical $\mathrm{pO}_{2}$ of $5-15 \mathrm{mmHg}$ and a normal $\mathrm{pO}_{2}$ of $20-50 \mathrm{mmHg}[3,12,14,22,23]$. This study shows, that several technical in-vitro preconditions of both oxygen tension measurement methods are be fulfilled. The Bland-Altman plot (Fig. 2B) indicates that both methods produce similar and reliable oxygen values over a broad range of oxygen concentrations, although there are greater variations between the NT sensors than between the LX sensors (see also Fig. 2A). However, there is still a lack of evidence whether the results are comparable during routine clinical use in the human brain. Furthermore, despite absolute readings of $\mathrm{pO}_{2}$, the duration of low $\mathrm{pO}_{2}$ should be taken into account along with the fact that a heterogeneous $\mathrm{pO}_{2}$ distribution in brain tissue can result in variable $\mathrm{pO}_{2}$ readings. As shown in this study, sensors measure $\mathrm{pO}_{2}$ at low $\mathrm{pO}_{2}$ increasingly differently compared with the expected 
$\mathrm{pO}_{2}$, e.g. less than $15 \mathrm{mmHg}$ (calibration gas \#1 and \#2). Zauner et al. [25] presented an in vitro setup with using the Paratrend 7 sensor, which is a Clarc-type electrode in contrast to the fluorescent NT sensor. Probes were placed in an incubator filled with human packed cell units on $37^{\circ} \mathrm{C}$ and bubbled with different concentration of gases. 7 Paratrend readings were compared with intermitted blood gas analysis above $18 \mathrm{mmHg}$. The maximal difference for $\mathrm{pO}_{2}$ was less than $8 \mathrm{mmHg}$. However, these results are just valid for $\mathrm{pO}_{2}>18 \mathrm{mmHg}$. In addition, possible heterogeneous distribution of oxygen within the incubator as well as a possible inaccuracy of the blood gas analyser might cause additional bias. For this reason, we suggest that choosing highly precise calibration gases bubbled in a buffer solution as performed in this experiment allows very accurate calculation of $\mathrm{pO}_{2}$ and therefore can minimise these variables. Moreover, the in vitro results of Zauner et al. [25] can not be adopted for the NT probe because of the completely different $\mathrm{pO}_{2}$ sensor technology. Until now no comparable study exists analysing the accuracy of $\mathrm{pO}_{2}$ sensors for application in human brain. Notably the frequently performed " $100 \%$ inspired oxygen test" to check if the oxygen tension sensor is working properly should take into consideration a relatively high $90 \%$ response time of $129 \pm 27 \mathrm{sec}$ for LX sensor compared with $55 \pm 19 \mathrm{sec}$ for the NT sensor. This result reflects that both sensors are not directly comparable in clinical use. Clinical experience with LX probes suggests that a much quicker response time is achieved in brain tissue. The used in vitro setup in this study might not represent an ideal comparison for reaction time of the two probe types. The additional temperature measurement of NT with simultaneous temperature corrected $\mathrm{pO}_{2}, \mathrm{pCO}_{2}$ and $\mathrm{pH}$ measurements eliminates errors in $\mathrm{pO}_{2}$ calculation. For LX, this has to be done either manually $\left(1^{\circ} \mathrm{C}\right.$ steps on LX monitor) which yields a slight inaccuracy of $\mathrm{pO}_{2}$ readings or by adding an additional temperature probe connected to the monitor. A recent study comparing different temperature probes revealed very precise temperature readings at a range of $30-42{ }^{\circ} \mathrm{C}$ for both LX and NT systems [1]. Although this study implies that in vitro the NT technology measures $\mathrm{pO}_{2}, \mathrm{pCO}_{2}$ and $\mathrm{pH}$ accurately enough in the physiological range $\left(\mathrm{pO}_{2}\right.$ 7-57 mmHg, $\mathrm{pCO}_{2} 36-114 \mathrm{mmHg}, \mathrm{pH}$ 6.8-7.4), there is - in contrast to LX and Paratrend sensors-conflicting data of evidence that this new fiberoptic catheter technology is able to provide reliable monitoring data in clinical practice [9]. Thus, in vivo evaluation in animals is necessary to study sensor properties in physiological and pathophysiological conditions to further analyse its purpose as a cerebral monitoring tool in humans.

\section{Conclusion}

In vitro accuracy of LX and NT probes measuring oxygen tension seems sufficient in all tested oxygen and carbon dioxide concentrations, even if the NT sensor measured significantly lower in $1 \% \mathrm{O}_{2}$-concentration. Also for long-term use there is only a slight drift towards lower oxygen tension readings for both sensors, but more pronounced for the NT. $\mathrm{pCO}_{2}$ and $\mathrm{pH}$ measurement performed by NT is very precise. Both sensors show a shorter response time to $\mathrm{pO}_{2}$ increase compared with $\mathrm{pO}_{2}$ decrease. For both directions, LX needs more time to reach a $90 \%$ response compared with NT.

\section{Acknowledgement}

This study was financially supported by Codman\&Shurtleff, Raynham, USA. However, the authors confirm that the results of this study were not influenced by this support and all published data are presented without any interest for personal or financial advantage. We are also grateful to Nick Barnett Ph.D. (Diametrics Medical Ltd, Wycombe, UK), Andrea Hupp and Sven Gross (both Codman, Hamburg, Germany) supporting us with any information and material needed to perform this study.

\section{References}

1. Alessandri B, Hoelper BM, Behr R, Kempski O (2004) Accuracy and stability of temperature probes for intracranial application. J Neurosci Methods 139: 161-165

2. Charbel FT, Du X, Hoffman WE, Ausman JI (2000) Brain tissue $\mathrm{PO}(2), \mathrm{PCO}(2)$, and pH during cerebral vasospasm. Surg Neurol 54: 432-437; discussion 438

3. Dings J, Jager A, Meixensberger J, Roosen K (1998) Brain tissue $\mathrm{pO}_{2}$ and outcome after severe head injury. Neurol Res 20: $\mathrm{S} 71-\mathrm{S} 75$

4. Dings J, Meixensberger J, Jager A, Roosen K (1998) Clinical experience with 118 brain tissue oxygen partial pressure catheter probes. Neurosurgery 43: 1082-1095

5. Hoelper BM, Hofmann E, Sporleder R, Soldner F, Behr R (2003) Transluminal balloon angioplasty improves brain tissue oxygenation and metabolism in severe vasospasm after aneurysmal subarachnoid hemorrhage: case report. Neurosurgery 52: 970-976

6. Hoffman WE, Charbel FT, Edelman G, Hannigan K, Ausman JI (1996) Brain tissue oxygen pressure, carbon dioxide pressure and $\mathrm{pH}$ during ischemia. Neurol Res 18: 54-56

7. Hutchinson PJ, Al-Rawi PG, O'Connell MT, Gupta AK, Pickard JD, Kirkpatrick PJ (2000) Biochemical changes related to hypoxia during cerebral aneurysm surgery: combined microdialysis and tissue oxygen monitoring: case report. Neurosurgery 46: 201-205; discussion 205-206

8. Kautsky H, Briujn HD (1931) Die Aufklärung der Photoluminescenztilgung fluorescierender Systeme durch Sauerstoff: Die Bildung aktiver, diffusionsfähiger Sauerstoffmoleküle durch Sensibilisierung. Naturwissenschaften 19: 1043 
9. Kett-White R, Hutchinson PJ, Al-Rawi PG, Gupta AK, Pickard JD, Kirkpatrick PJ (2002) Adverse cerebral events detected after subarachnoid hemorrhage using brain oxygen and microdialysis probes. Neurosurgery 50: 1213-1221

10. Khaldi A, Zauner A, Reinert M, Woodward JJ, Bullock R (2001) Measurement of Nitric Oxide and Brain Tissue Oxygen Tension in Patients after Severe Subarachnoid Hemorrhage. Neurosurgery 49: 33-40

11. Kiening KL, Hartl R, Unterberg AW, Schneider GH, Bardt T, Lanksch WR (1997) Brain tissue $\mathrm{pO}_{2}$-monitoring in comatose patients: implications for therapy. Neurol Res 19: 233-240

12. Kiening KL, Unterberg AW, Bardt TF, Schneider GH, Lanksch WR (1996) Monitoring of cerebral oxygenation in patients with severe head injuries: brain tissue $\mathrm{pO}_{2}$ versus jugular vein oxygen saturation. J Neurosurg 85: 751-757

13. Maas AI, Fleckenstein W, de Jong DA, van Santbrink H (1993) Monitoring cerebral oxygenation: experimental studies and preliminary clinical results of continuous monitoring of cerebrospinal fluid and brain tissue oxygen tension. Acta Neurochir (Wien) [Suppl] 59: 50-57

14. Mahutte CK (1997) Continuous intravascular and on-demand extravascular arterial blood-gas monitoring. In: Tobin MJ (ed) Principles and practice of intensive care monitoring. McGraw-Hill, New York, pp 243-259

15. Meixensberger J, Dings J, Jäger A, Baunach S, Roosen K (1998) Die Gewebesauerstoffmessung im Gehirn - Was ist bewiesen? Intensivmed 35 [Suppl] 1: 72-79

16. Peterson JI, Vurek GG (1984) Fiber-optic sensors for biomedical applications. Science 224: 123-127

17. Sarrafzadeh AS, Sakowitz OW, Callsen TA, Lanksch WR, Unterberg AW (2002) Detection of secondary insults by brain tissue $\mathrm{pO}_{2}$ and bedside microdialysis in severe head injury. Acta Neurochir (Wien) [Suppl] 81: 319-321

18. Schneider GH, Sarrafzadeh AS, Kiening KL, Bardt TF, Unterberg AW, Lanksch WR (1998) Influence of hyperventilation on brain tissue- $\mathrm{pO}_{2}, \mathrm{PCO}_{2}$, and $\mathrm{pH}$ in patients with intracranial hypertension. Acta Neurochir (Wien) [Suppl] 71: 62-65

19. Steiner T, Pilz J, Schellinger P, Wirtz R, Friederichs V, Aschoff A, Hacke W (2001) Multimodal online monitoring in middle cerebral artery territory stroke. Stroke 32: 2500-2506

20. Stern O, Volmer M (1919) Über die Abklingzeit der Fluorescenz. Z Phys 20: 183-188

21. Unterberg AW, Kiening KL, Hartl R, Bardt T, Sarrafzadeh AS, Lanksch WR (1997) Multimodal monitoring in patients with head injury: evaluation of the effects of treatment on cerebral oxygenation. J Trauma 42: S32-S37

22. Valadka AB, Gopinath SP, Contant CF, Uzura M, Robertson CS (1998) Relationship of brain tissue $\mathrm{pO}_{2}$ to outcome after severe head injury. Crit Care Med 26: 1576-1581
23. van den Brink WA, van Santbrink H, Steyerberg EW, Avezaat CJ, Suazo JA, Hogesteeger C, Jansen WJ, Kloos LM, Vermeulen J, Maas AI (2000) Brain oxygen tension in severe head injury. Neurosurgery 46: 868-876

24. van Santbrink H, Maas AI, Avezaat CJ (1996) Continuous monitoring of partial pressure of brain tissue oxygen in patients with severe head injury [see comments]. Neurosurgery 38: $21-31$

25. Zauner A, Bullock R, Di X, Young HF (1995) Brain oxygen, $\mathrm{CO}_{2}$, $\mathrm{pH}$, and temperature monitoring: evaluation in the feline brain. Neurosurgery 37: 1168-1176

26. Zauner A, Doppenberg E, Woodward JJ, Allen C, Jebraili S, Young HF, Bullock R (1997) Multiparametric continuous monitoring of brain metabolism and substrate delivery in neurosurgical patients. Neurol Res 19: 265-273

27. Zauner A, Doppenberg EM, Woodward JJ, Choi SC, Young HF, Bullock R (1997) Continuous monitoring of cerebral substrate delivery and clearance: initial experience in 24 patients with severe acute brain injuries. Neurosurgery 41: 1082-1091

\section{Comments}

The authors have described a carefully designed in-vitro bench test study comparing the long-term zero drift and response time of the two main commercially available $\mathrm{PO}_{2}$ sensor systems.

Such carefully controlled bench tests are useful as a method for comparing technologies, which might not either be practical or ethical in clinical studies. The authors have accurately defined the zero drift and response times of the two systems and have provided useful technical information to others wishing to use either technologies.

\section{Ian Piper} Glasgow

This is a very useful and topical laboratory study, comparing static and dynamic accuracy of two tissue oxygenation sensors.

Dynamic properties of both sensors were compared- and this is of special values, when various 'dynamic autoregulation' indices have just been introduced based on the brain tissue oxygenation.

Laboratory setup was unable to simulate small and relatively fast changes in brain oxygenation, as they observed in practice and most probably provoked by fluctuation of rCBF- and this is a limitation of the laboratory dynamic test.

\section{Czosnyka Cambridge}

Correspondence: Bernd Manfred Hoelper, Department of Neurosurgery, Klinikum Fulda, Pacelliallee 4, 36043 Fulda, Germany. e-mail: hoelper@online.de 